\title{
Karyotype Analysis in Some Salvia species (Lamiaceae) of Iran
}

\author{
Masoud Sheidai ${ }^{1 *}$ and Behnaz Alijanpoo ${ }^{2}$ \\ ${ }^{1}$ Faculty of Biological Sciences, Shahid Beheshti University, Tehran, Iran \\ ${ }^{2}$ Center of Excellence in Phylogeny of Living Organisms, College of Science, \\ University of Tehran, 14155-6455 Tehran, Iran
}

Received March 20, 2011; accepted July 25, 2011

\begin{abstract}
Summary Karyotype analysis was performed in 10 Salvia species (Lamiaceae) of Iran, S. spinosa, S. reuterana, S. sclarea, S. ceratophylla, S. xanthocheiala, S. limbata, S. hypoleuca, S. staminea, S. nemorosa and $S$. verticillata showing $2 n=14,20,22$ and 32 chromosome numbers indicating the role played by polyploidy and aneuploidy in Salvia species diversification. Some of the species differed significantly in the size of chromosomes but occupied 1A and 1B classes of Stebbins system indicating them to have primitive karyotype.
\end{abstract}

Key words Karyotype, Salvia, Stebbins system, Species diversification.

The genus Salvia L. (Lamiaceae) contains about 900 herbaceous, suffruticose or shrubby perennials, rarely biennial or annual, often strongly aromatic species mainly growing in temperate and subtropical areas with Western Asia and Mediterranean regions as the main center of their distribution (Standley and Williams 1973, Özdemir and Senel 1999, Wu and Li 1982). These species are of horticultural, commercial and medicinal values (Bhattacharya 1978).

Rechinger et al. (1982) reported 70 Salvia species in Flora Iranica, showing greate morphological diversity possibly due to Inter-specific hybridization. He belives that although some of the species are very distinct, others show close affinity with other species and some species are in a state of evolutionary flux.

Cytological studies carried out in the genus Salvia revealed the occurrence of diverse chromosome numbers indicating that the genus seems to be polybasic, with different groups of species in different parts of the world having polyploid origins. According to Afzal-Rafii (1976), Salvia species of the Mediterranean region have $x=7$, while Patudin et al. (1975) believe that Salvia species of Europe and Russia have $x=11$ and finally Epling et al. (1962) consider the species growing in California to have $x=16$. Moreover, studies made by Palomino et al. (1986), show that Salvia subgenus Calosphace is characterized by $x=11$ and lower numbers.

In general, extensive cytological studies exist in the genus Salvia from different parts of the world (for example, Patudin et al. 1975, Lee 1967, Afzal-Rafii 1976, Mizianti et al. 1981, Haque 1981, Borgen 1980, Díaz-Lifante et al. 1992, Palomino et al. 1986, Özdemir and Senel 1999, Yildiz and Güccel 2006, Bahattacharya 1978, Foley et al. 2008). However, cytological reports from Salvia species of Iran are very limited (Ghaffari and Chariat-Panahi 1985, Estilai and Hashemi 1990, Sheidai et al. 2010). The present study considers the karyptype analysis of 10 Salvia species growing wild in Iran for the first time.

\footnotetext{
*Corresponding author, e-mail: msheidai@yahoo.com,msheidai@sbu.ac.ir
} 
Table 1.

\begin{tabular}{lllllllllllllllll}
\hline \hline \multicolumn{1}{c}{ Species } & Locality & Voucher & $\begin{array}{c}2 \mathrm{n} \\
\text { Level }\end{array}$ & $\begin{array}{c}\text { Ploidy } \\
(\mu \mathrm{m})\end{array}$ & $\begin{array}{c}\mathrm{TL} \\
(\mu \mathrm{m})\end{array}$ & $\begin{array}{c}\mathrm{L} \\
(\mu \mathrm{m})\end{array}$ & $\mathrm{S}$ & $\begin{array}{c}\mathrm{L} / \mathrm{S} \\
(\mu \mathrm{m})\end{array}$ & $\mathrm{X}$ & $\mathrm{ST}$ & $\mathrm{A} 1$ & $\mathrm{~A} 2$ & $\mathrm{TF}$ & $\mathrm{KF}$ \\
\hline S. nemorosa & Gachsar & 8500981 & 14 & $2 \mathrm{x}$ & 15.40 & 2.65 & 1.69 & 1.57 & 2.20 & $1 \mathrm{~A}$ & 0.25 & 0.11 & 47.00 & $7 \mathrm{~m}$ \\
S. nemorosa & Khojir & 8500984 & 14 & $2 \mathrm{x}$ & 15.67 & 2.82 & 1.66 & 1.69 & 2.24 & $1 \mathrm{~A}$ & 0.26 & 0.00 & 42.74 & $7 \mathrm{~m}$ & \\
S. reuterana & Khojir & 8501000 & 20 & $2 \mathrm{x}$ & 18.89 & 2.47 & 1.30 & 1.89 & 1.89 & $1 \mathrm{~A}$ & 0.26 & 0.17 & 42.62 & $10 \mathrm{~m}$ & \\
S. spinosa & Khojir & 8501004 & 20 & $2 \mathrm{x}$ & 16.55 & 2.32 & 1.08 & 2.15 & 1.65 & $1 \mathrm{~B}$ & 0.27 & 0.18 & 42.64 & $10 \mathrm{~m}$ \\
S. hypoleuca & Khojir & 8500986 & 22 & $2 \mathrm{x}$ & 21.90 & 2.69 & 1.26 & 2.13 & 1.99 & $1 \mathrm{~B}$ & 0.32 & 0.17 & 40.38 & $10 \mathrm{~m}+1 \mathrm{sm}$ \\
S. limbata & Khojir & 8500992 & 22 & $2 \mathrm{x}$ & 21.51 & 2.58 & 1.32 & 2.00 & 1.98 & $1 \mathrm{~B}$ & 0.30 & 0.19 & 41.00 & $11 \mathrm{~m}$ \\
S. staminea & Abali & 8500999 & 22 & $2 \mathrm{x}$ & 27.78 & 3.48 & 1.66 & 2.10 & 2.53 & $1 \mathrm{~B}$ & 0.26 & 0.18 & 42.45 & $11 \mathrm{~m}$ \\
S. ceratophylla & Sorkhehesar & 8500990 & 22 & $2 \mathrm{x}$ & 22.73 & 2.69 & 1.46 & 1.85 & 2.07 & $1 \mathrm{~A}$ & 0.27 & 0.15 & 45.86 & $10 \mathrm{~m}+1 \mathrm{sm}$ \\
S. sclarea & Polur & 8500998 & 22 & $2 \mathrm{x}$ & 20.30 & 2.45 & 1.31 & 1.87 & 1.85 & $1 \mathrm{~A}$ & 0.27 & 0.14 & 42.04 & $10 \mathrm{~m}+1 \mathrm{sm}$ \\
S. xanthocheila & Polur & 8501006 & 22 & $2 \mathrm{x}$ & 21.27 & 2.70 & 1.47 & 1.84 & 1.93 & $1 \mathrm{~A}$ & 0.28 & 0.15 & 41.54 & $11 \mathrm{~m}$ \\
S. verticellata & Gschsar & 8500997 & 32 & $4 \mathrm{x}$ & 37.74 & 3.16 & 1.70 & 1.86 & 2.36 & $1 \mathrm{~A}$ & 0.26 & 0.14 & 42.17 & $16 \mathrm{~m}$ \\
\hline
\end{tabular}

Abbreviations: $\mathrm{TL}=$ Total chromosome length, $\mathrm{L}=$ Size of the longest chromosome, $\mathrm{S}=$ Size of the shortest chromosome, $\mathrm{L} / \mathrm{S}=$ Ratio of the longest chromosome/shortest chromosome, $\mathrm{X}=$ The mean chromosome length, $\mathrm{ST}=\mathrm{Stebbins}$, class, A1 and $\mathrm{A} 2=$ Romero-Zarco indices, $\mathrm{TF}=$ Total form percentage and $\mathrm{KF}=$ Karyotype formulae.

Materials and methods

\section{Plant material}

Plant materials collection was done in the Central Alborze region during 2009 and 2010. Cytological studies were performed in 11 populations of 10 Salvia species growing wild in this region, namely S. spinosa L., S. reuterana Boiss., S. sclarea (Mönch) Benth., S. ceratophylla L., S. xanthocheiala Boiss. ex. Benth., S. limbata C. A. Mey., S. hypoleuca Benth., S. staminea Monthbr. \& Auch. ex. Benth., S. nemorosa L., and S. verticillata L. The voucher specimens are deposited in Herbarium of Shahid Beheshti University (HSBU), details of which have been given in Table 1.

\section{Cytological studies}

For the karyotype study, freshly grown root tips were collected from germinated seed of at least ten randomly selected plants in each species, pretreated with $0.002 \mathrm{~mol} 8$-hydroxyquinolin (2$2.5 \mathrm{~h}$ ) and fixed in ethanol-acetic acid $(3: 1)$ for $24 \mathrm{~h}$. The fixed tips were then washed thoroughly in distilled water, macerated in $60^{\circ} \mathrm{C} 1 \mathrm{~N} \mathrm{HCl}$ for about $5 \mathrm{~min}$., and squash in $2 \%$ aqueous aceo-orcein stain solution. The somatic chromosome number and karyotype details were studied in at least 5 well-prepared metaphase plates. The chromosomes were photographed by digital camera and measured by Image Tools3 software (Sheidai and Jalilian 2008).

\section{Karyotype description}

The chromosomes were described according to Levan et al. (1964), karyotype symmetry was determined according to Stebbins (1971), while other karyotype parameters like haploid total chromosome length (total sum of the size of the chromosomes by using only 1 chromosome from each pair), mean chromosome length (total haploid chromosome length/number of chromosome pairs), total form percentage ( $\mathrm{TF} \%=$ Sum of short arms of the chromosomes/total chromosome length) as well as the A1 and A2 indices of Romero-Zarco (1986) were determined (Sheidai and Jalilian 2008).

\section{Statistical analyses}

In order to reveal significant difference among the species and populations studied, the analysis of variance (ANOVA) (Sheidai and Jalilian 2008) followed by the least significant difference test (LSD) were performed on the size of chromosomes, size of the long arms and size of the short 


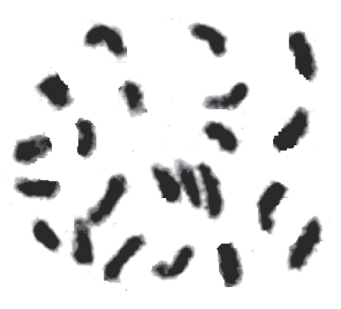

A

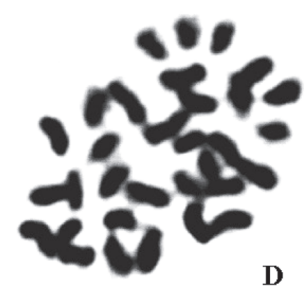

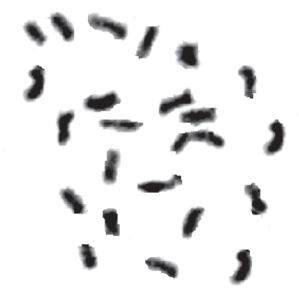

B

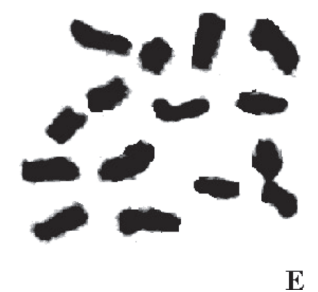

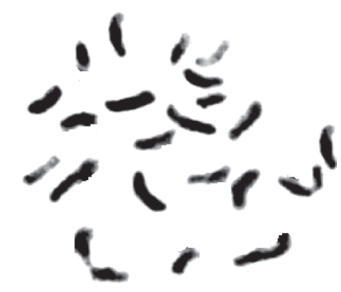

C

Fig. 1. Representative somatic metaphase cells in Salvia species studied. A-E=S. ceratophylla, S. hypoleuca, S. limbata, S. verticellata and $S$. nemorosa, respectively. Scale bar $=10 \mu \mathrm{m}$.

arms as well as arms ratio among the species and populations studied (Sheidai and Jalilian 2008).

\section{Results and discussion}

Details of karyotypes are presented in Table 1, Fig. 1 . The species studied had $2 n=14,20,22$ and 32 chromosome numbers. S. nemorosa showed $2 n=14$ in both populations of Gashsar and Kojir, supporting the earlier reports (Mizianti et al. 1981, Ghaffari and Chariat-Panahi 1985), S. reuteriana and $S$. spinosa showed $2 n=20$, supporting the earlier reports (Afzal-Rafii 1981, Ghaffari and Chariat-Panahi 1985, Sheidai et al. 2010). S. hypoleuca, S. ceratophylla, S. limbata and S. sclarea, $S$. staminea and $S$. xanthocheila showed $2 n=22$ chromosome number, supporting previous reports (Afzal-Rafii 1980, 1981, Özdemir and Senel 1999), S. verticillata showed $2 n=4 x=32$ supporting the reports of Afzal-rafii (1980) and Lövkvist and Hultgård (1999).

There are several reports on the occurrence of multiple basic chromosome numbers in a single Salvia species, including 2n=12, 26 and 28 for S. aegyptiaca L., (Haque 1981, Borgen 1980, DíazLifante et al. 1992), $2 n=14$ and 16 for S. chanroenica ssp. glomerifolia Chung (Lee 1967), and for S. nemorosa L. (Mizianti et al. 1981, Ghaffari and Chariat-Panahi 1985). The reason for such multiple basic numbers is the occurrence of polyploidy and aneuploidy in Salvia species possibly for adaptation to the various environmental conditions the species are facing. In fact, such cytological variations may be one of the causes of extensive morphological diversity reported in Salvia species (Rechinger et al. 1982).

Controversy exists about the primitive versus advanced nature of chromosome base numbers in the genus Salvia. According to Bahattacharya (1978), base numbers 7 and 8 are the primitive base numbers from which secondary base numbers became established and diversified in different directions, forming the base number 11 which is frequent in many species.

The chromosomes were mostly metacentric with a only 1 pair of sub-metacentric chromosome occurring in S. hypoleuca, S. ceratophylla and S. sclarea (Table 1).

The size of the longest chromosome pair varied from $2.32 \mu \mathrm{m}$ in $S$. spinosa to $3.48 \mu \mathrm{m}$ in $S$. staminea, while the size of shortest chromosome pair ranged from $1.80 \mu \mathrm{m}$ in $S$. spinosa to $1.70 \mu \mathrm{m}$ in $S$. verticellata. Similarly the mean chromosome lenth varied from $1.65 \mu \mathrm{m}$ in $S$. spinosa to $2.53 \mu \mathrm{m}$ in $S$. staminea. 
$t$-Test analysis showed no significant difference in size of the chromosomes and chromosome arms between 2 populations of $S$. nemorosa with $2 n=14$ and also between $S$. reuterana and $S$. spinosa having $2 n=20$. However the ANOVA test performed among the species having $2 n=22$ showed significant difference in total chromosome length, size of the longest chromosome pair and size of the shortest chromosome pair. Therefore, cytological changes in the species having $2 n=22$ consist of significant quantitative changes in the size of chromosomes (DNA).

The Stebbins classes occupied by Salvia species are 1A and 1B which are considered as primitive classes and TF value above 40 indicates a symmetrical karyotype.

Controversy also exists about the primitive versus advance nature of the genus Salvia itself, for example Fujita (1970), considered Salvia as the most primitive genus in the family Labiateae with the highest primary basic number 11 although Ajuga is often considered as the most primitive genus. However, according to Bahattacharya (1978), due to cytological numerical instability, the presence of highly irregular cytological behavior and presence of advanced karyotype in the Salvia species, they are recent and advanced members of a complex group. However, the present study shows that Salvia species studied have primitive (symmetrical) karyotypes as they occupy 1A and $1 \mathrm{~B}$ classes of the Stebbins system and also show a very low degree of size difference among the chromosomes.

\section{References}

Afzal-Rafii, Z. 1976. Etude cytotaxonomique et phylogenetique de quelques Salvia de la region mediterraneenne: Groupe du Salvia officinalis. L. Acta Bot. Gall. 123: 515-531.

—. 1980. In chromosome number reports LXVII. Taxon 29: 365-366.

-. 1981. In chromosome number reports LXX. Taxon 30: 73-74.

Bhattacharya, S. 1978. Study of Some Indian Members of the Genus Salvia with references to the cytological Behaviour. Cytologia 43: 317-324.

Borgen, L. 1980. Chromosome numbers of Macaronesian flowering plants III. Botanica Macaronésia 7: 67-76.

Díaz-Lifante, Z., Luque, T. and Santa Bárbara, C. 1992. Chromosome numbers of plants collected during Iter Mediterraneum II in Israel. Bocconea, Monographiae Herbarii Mediterranei Panormitani 3: 229-250.

Epling, C., Lewis, H. and Raven, P. 1962. Chromosomes of Salvia: Sect. Audibertia. Aliso 5: 217-221.

Estilai, A. and Hashemi, A., 1990. Chromosome number and meiotic behavior of cultivated Chia, Salvia hispanica (Lamiaceae). HortScience 25: 1646-1647.

Fujita, Y. 1970. Evolution of chromosome numbers in the Labiaceae, especially its relation to the classification and phylogeny of the genus Salvia based on constituents of essential oils. APG 24: 113-121.

Foley, M. J. Y., Hedge, I. C. and Müller, M. 2008. The enigmatic Salvia tingitana (Lamiaceae): A case study in history, taxonomy and cytology. Willdenowia 38: 41-59.

Ghaffari, S. M. and Chariat-Panahi, M. S. 1985. Chromosome counts of some angiosperms from Iran. Iranian J. Bot. 3: 6773.

Haque, M. S. 1981. Chromosome numbers in the genus Salvia Linn. Proc Indian Natl Sci Acad B Biol Sci 47: 419-426.

Lee, Y. N. 1967. Chromosome numbers of flowering plants in Korea. Journal Korean Research Institute Ewha Women's University 11: 455-478.

Levan, A., Fredga, K. and Sandberg, A. 1964. Nomenclature for centromeric position on chromosomes. Hereditas 52: 201220 .

Lövkvist, B. and Hultgård, U. M. 1999. Chromosome numbers in south Swedish vascular plants. Opera Bot. 137 : 1-42.

Mizianti, M., Frey, L. and Mirek, Z. 1981. Contribution to the knowledge of the chromosome numbers of Polish vascular plants. Fragmenta Floristica et Geobotanica Polonica 27: 19-29.

Özdemir, C. and Senel, G. 1999. The morphological, anatomical and karyological properties of Salvia sclarea L. Turk. J. Bot 23: 7-18.

Palomino, G., Mercado', P. and Ramamoorthy, T. P. 1986. Chromosomes of Salvia subgenus Calosphace (Lamiaceae), a preliminary report. Cytologia 51: 381-386.

Patudin, A. V., Yurtsev, V. N. and Pakaln, D. A. 1975. Chromosome numbers in some species of Salvia L. (Lamiaceae). Bot. Z. 60: 529-534.

Rechinger, K. H., Hedge, C., Ietswaart, J. H., Jalas, J., Mennema, J. and Seybold, S. 1982. In: K. H. Rechinger (ed.). Labiateae in Flora Iranica, No. 150, Akademische Druck. Verlagsanstalt, Graz. Pp. 403-412. 
Romero-Zarco, C. 1986 A new method for estimating karyotype asymmetry. Taxon 35: 526-530.

Sheidai, M. and Jalilian, N. 2008. Karyotypic studies in some species and populations of the genus Lotus L. in Iran. Acta Bot Croat 67: 45-52.

-, Alijanpoor, B. and Khayyami, M. 2010. Contribution to cytology of genus Salvia L. (Lamiaceae) in Iran. Caryologia 63: 405-410.

Standley, P. and Williams, L. 1973. Labiateae. Fieldiana Bot 24: 237-317.

Stebbins, G. L. 1971. Chromosomal Evolution in Higher Plants. Edward Arnold, London.

Wu, C. Y. and Li, H. W. 1982. On the evolution and distribution in Labiateae. Yunnnan Zhi Wu Yan Jin 4: 97-118.

Yildiz, K. and Gücel, S. 2006. Chromosome numbers of 16 endemic plant taxa from Northern Cyprus. Turk. J. Bot. 30: 181-192. 